\title{
Cloning and expression of recombinant human pineal tryptophan hydroxylase in Escherichia coli: purification and characterization of the cloned enzyme
}

\author{
Devanand Kowlessur ${ }^{1}$, Seymour Kaufman * \\ Laboratory of Neurochemistry, National Institute of Mental Health, National Institutes of Health, Building 36, Room 3D/30, 36, \\ Convent Drive MSC 4096, Bethesda, MD 20892-4096, USA
}

Received 10 May 1999; received in revised form 3 August 1999; accepted 3 August 1999

\begin{abstract}
The first step in the biosynthesis of melatonin in the pineal gland is the hydroxylation of tryptophan to 5hydroxytryptophan. A cDNA of human tryptophan hydroxylase (TPH) was cloned from a library of human pineal gland and expressed in Escherichia coli. This cDNA sequence is identical to the cDNA sequence published from the human carcinoid tissue [1]. This human pineal hydroxylase gene encodes a protein of 444 amino acids and a molecular mass of 51 $\mathrm{kDa}$ estimated for the purified enzyme. Tryptophan hydroxylase from human brainstem exhibits high sequence homology ( $93 \%$ identity) with the human pineal hydroxylase. The recombinant tryptophan hydroxylase exists in solution as tetramers. The expressed human pineal tryptophan hydroxylase has a specific activity of $600 \mathrm{nmol} / \mathrm{min} / \mathrm{mg}$ when measured in the presence of tetrahydrobiopterin and L-tryptophan. The enzyme catalyzes the hydroxylation of tryptophan and phenylalanine at comparable rates. Phosphorylation of the hydroxylase by protein kinase A or calmodulin-dependent kinase II results in the incorporation of $1 \mathrm{~mol}$ of phosphate/mol of subunit, but this degree of phosphorylation leads to only a modest (30\%) increase in $\mathrm{BH}_{4}$-dependent activity when assayed in the presence of 14-3-3. Rapid scanning ultraviolet spectroscopy has revealed the formation of the transient intermediate compound, $4 \alpha$-hydroxytetrahydrobiopterin, during the hydroxylation of either tryptophan or phenylalanine catalyzed by the recombinant pineal TPH. (C) 1999 Elsevier Science B.V. All rights reserved.
\end{abstract}

Keywords: Tryptophan hydroxylase; Tetrahydrobiopterin; Melatonin; Hyperphenylalaninemia; Carbinolamine dehydratase

Abbreviations: $\mathrm{BH}_{4},(6 R)-5,6,7,8$-tetrahydrobiopterin; $6 \mathrm{MPH}_{4}, 6$-methyl-5,6,7,8-tetrahydropterin; $\mathrm{DMPH}$, 6,7-dimethyl-5,6,7,8-tetrahydropterin; $7 \mathrm{BH}_{4},(7 R)-5,6,7,8$-tetrahydrobiopterin; SDS, sodium dodecyl sulfate; TPH, tryptophan hydroxylase; IPTG, isopropyl- $\beta$-Dthiogalactopyranoside; PKA, protein kinase A (catalytic subunit); CaMKII, calmodulin kinase II; PHS, phenylalanine hydroxylase stimulating protein (also known as $4 \alpha$-pterin carbinolamine dehydratase); PAH, phenylalanine hydroxylase; TH, tyrosine hydroxylase; 14-3-3, members of an abundant mammalian brain protein family that migrate to a particular pattern on two-dimensional DEAEcellulose chromatography

* Corresponding author. Fax: (301) 4809284; E-mail: kaufman@codon.nih.gov

1 Present address: Department of Neurology, University of Chicago, 5841 South Maryland Avenue, Chicago, IL 60637, USA. 


\section{Introduction}

Tryptophan hydroxylase (TPH; EC 1.14.16.4) catalyzes the initial step in the biosynthesis of serotonin in the serotonergic neuron and of melatonin in the pineal gland [2]. Tryptophan hydroxylase catalyzes the following reaction:

$\mathrm{L}-$ tryptophan $+\mathrm{O}_{2}+\mathrm{BH}_{4} \rightarrow$

5 - hydroxytryptophan +

quinonoid $\mathrm{H}_{2}$ biopterin $+\mathrm{H}_{2} \mathrm{O}$

In mammals, TPH is expressed in a limited number of tissues, mainly the brainstem raphe nuclei [3], and the pineal gland [4] and is associated with neurons innervating the gut [5]. Serotonin has been implicated in a wide range of physiological functions, such as blood pressure control, sleeping behavior and appetite. In addition, malfunction of serotonergic neurons has been implicated in various psychiatric disorders such as depression and impulsive behaviors such as aggression, suicide, and drug abuse [6,7].

The cDNA encoding rabbit and rat TPH have been cloned from pineal gland. This was followed by the isolation of homologous human and mouse cDNA from carcinoid cell line and mastocytoma cDNA [1,8-10]. Only recently, the catalytically active forms of the human and rat recombinant TPH have been cloned and expressed [11-14]. One major problem has been the instability and insolubility of TPH expressed in Escherichia coli. The problem of the insolubility of the cloned enzyme and its occurrence in inclusion bodies has been partially overcome by expressing the enzyme in fusion expression systems in E. coli $[14,15]$. On the other hand, expression as a fusion protein can lead to problems due to the inability to cleave the TPH from fusion protein [14,15]. Recently, the expression and characterization of the catalytic core of TPH has been reported but none of its regulatory properties have been investigated [16]. In the present report, we describe for the first time the cloning, expression and purification of recombinant human pineal TPH in a bacterial system that circumvents the problems of the enzyme's insolubility, instability and its presence in inclusion bodies.

A number of laboratories have reported that TPH can be activated by CaMKII and PKA in the pres- ence of an activator now identified as a member of the family of proteins named 14-3-3 [17-19]. Recent studies with recombinant rabbit TPH have provided some insight into the molecular mechanism of activation of phosphorylated TPH by 14-3-3 [20]. In the present study, we have demonstrated that $14-3-3$ is also able to stimulate the activity of phosphorylated pineal TPH. With the pure TPH, we have also succeeded in demonstrating the formation of $4 \alpha$-hydroxytetrahydrobiopterin as a product of the hydroxylation of tryptophan to 5-hydroxytryptophan and have shown that pterin carbinolamine dehydratase can stimulate the hydroxylation reaction.

\section{Materials and methods}

\subsection{Materials}

Plasmid vector pET20b+ was obtained from Novagen. Host $E$. coli strains DH5 were from Bethesda Research Labs (Bethesda, MD) and BL21 (DE3) was obtained from Novagen. Restriction endonucleases and T4 DNA ligase were obtained from Bethesda Research Labs and New England Biolabs (Beverly, MA). Dideoxy sequencing reagents were from US Biochemicals and were used according to the manufacturer's recommendations. Reagents for the polymerase chain reaction were obtained from PerkinElmer (Norwalk, CT).

Bacterial growth medium was LB [21] $(0.5 \% \mathrm{NaCl}$, $1 \%$ tryptone, $0.5 \%$ yeast extract) supplemented with $100 \mu \mathrm{g} / \mathrm{ml}$ ampicillin, $0.1 \mathrm{mM}$ ferrous ammonium sulfate, and $0.6 \mathrm{mM}$ isopropyl- $\beta$-D-thiogalactopyranoside (IPTG) (for induction).

Phenylalanine, glucose 6-phosphate, tryptophan, glucose-6-phosphate dehydrogenase (from Leuconostoc mesenteroides), dihydropteridine reductase and protein kinase A, catalytic subunit, were obtained from Sigma. CaMKII and recombinant 14-3-3 $(\zeta$ form) from bovine brain were purchased from $\mathrm{Up}$ state Biotechnology (Lake Placid, NY). (6R)-Tetrahydrobiopterin, $(7 R, S)$-tetrahydrobiopterin and $(6 R, S)$-methyltetrahydropterin and 6,7-dimethyltetrahydropterin were obtained from Dr. B. Shircks laboratory (Jona, Switzerland). $\left[\gamma^{32} \mathrm{P}\right] \mathrm{ATP}$ was purchased from New England Nuclear (Boston, MA). Catalase was obtained from Boehringer Mannheim. 
Trifluoroperazine was purchased from Calbiochem. Recombinant rat dehydratase was purified from $E$. coli as described previously [22].

\subsection{Methods}

The TPH was cloned from a human pineal gland cDNA library (generous gift from Dr. David Klein, NIH). The fragment of DNA containing only the open reading frame was isolated directly from the library by means of PCR and ligated into the expression vector $\mathrm{pET} 20 \mathrm{~b}+$. Oligonucleotides GGAATTCCATATGATTGAAGACAATAAGGAGAACAAA (which incorporates a NdeI site immediately prior to the start codon) and CGGGATCCCGTTAGATACTC GGCTTCCTGC TGA CCTT (which incorporates a BamHI site after the stop codon) were used for this purpose. Optimum recovery of the TPH cDNA was achieved with $2 \mu \mathrm{l}$ of cDNA library in a $100 \mu 1$ reaction volume. Prior to the addition of the enzyme, the reaction mixture containing the primers and the template was melted by incubation at $94^{\circ} \mathrm{C}$ for $5 \mathrm{~min}$, and then the reaction was immediately started by the addition of Taq polymerase. The reaction was subjected to 30 cycles of the PCR reaction of $1 \mathrm{~min}$ at $94^{\circ} \mathrm{C}, 2 \mathrm{~min}$ at $45^{\circ} \mathrm{C}$ and $3 \mathrm{~min}$ at $72^{\circ} \mathrm{C}$. Several clones were isolated and subcloned in pET20b+. Both strands of each tryptophan hydroxylase clone were sequenced with the Sequenase sequencing kit. The correct sequence fragment (1.35 $\mathrm{kb}$ ) obtained was subcloned in pET20b+ (named pDKTPH).

\subsection{Preparation of pterin-agarose column}

The coupling of 2-amino-4-hydroxy-6,7-dimethyltetrahydropteridine to substituted agarose $\mathrm{ECH}$ Sepharose 4B Media (Pharmacia) was carried out by a modification of a published method [23]. Six ml of gel washed with distilled water was resuspended in $6 \mathrm{ml}$ of distilled water. The gel suspension was flushed with argon for $10 \mathrm{~min}$ and then $60 \mathrm{mg}$ of 2-amino-4hydroxy-6,7-dimethyltetrahydropteridine (dissolved in $5 \mathrm{mM} \mathrm{HCl}$ ) was added dropwise. The $\mathrm{pH}$ of the suspension was immediately adjusted to $\mathrm{pH} 5.0$ with $0.5 \mathrm{M} \mathrm{NaOH}$. The coupling reagent 1-ethyl-3-(3'-dimethylaminopropyl)carbodiimide hydrochloride (500 $\mathrm{mg}$ ), dissolved in $3 \mathrm{ml}$ of water, was added to the mixture which was kept under a stream of argon. After the addition of the coupling reagent, the $\mathrm{pH}$ was again adjusted to 5.0 and the mixture was stirred under a stream of argon for $10 \mathrm{~min}$. The mixture was sealed and shielded from light with aluminum foil and then shaken for $15 \mathrm{~h}$ at room temperature. The pterin content of the gel was determined as described previously [23]; for a typical preparation, a pterin content $8-10 \mu \mathrm{mol}$ of pterin/g of wet gel was obtained.

\subsection{Bacterial expression and purification}

The pineal TPH expression vector (pDKTPH) was transformed into the bacterial strain BL21[DE3] as described by Novagen. Cells containing pDKTPH were grown to mid-log phase in the presence of ampicillin in LB broth at room temperature and induced overnight with $0.5 \mathrm{mM}$ IPTG (isopropylthiogalactopyranoside), with the simultaneous addition of $0.1 \mathrm{mM}$ ferrous ammonium sulfate. The cells were harvested by centrifugation at $1000 \times g$ and resuspended in $100 \mathrm{ml}$ of sonication buffer $(50 \mathrm{mM}$ Tris-acetate $\mathrm{pH} 7.6$ containing $2 \mathrm{mM}$ dithiothreitol, $1 \mathrm{mM}$ phenylmethylsulfonyl fluoride, $2 \mu \mathrm{g} / \mathrm{ml}$ of leupeptin, $1 \mu \mathrm{g} / \mathrm{ml}$ of pepstatin, $2 \mu \mathrm{g} / \mathrm{ml}$ of aprotinin and $1 \mu \mathrm{g} / \mathrm{ml}$ of DNase). The cell suspension was sonicated on ice five times for $30 \mathrm{~s}$ on/off with a sonicator Ultrasonic Model W-225 processor with the maximal power set at $45 \%$ amplitude. The homogenate was centrifuged at $14000 \times g$ at $4^{\circ} \mathrm{C}$ for 30 min. The supernatant was brought to $50 \%$ saturation with ammonium sulfate and stirred for $20 \mathrm{~min}$ at $4^{\circ} \mathrm{C}$. The mixture was centrifuged at $14000 \times g$ at $4^{\circ} \mathrm{C}$ for $30 \mathrm{~min}$ and the resulting precipitate dissolved in $20 \mathrm{ml}$ of the equilibration buffer $(10 \mathrm{mM}$ sodium phosphate ( $\mathrm{pH} 7.0$ ) containing $10 \%$ glycerol, $0.06 \%$ Tween 20, $50 \mu \mathrm{M}$ EDTA and $1 \mathrm{mM}$ tryptophan (buffer A). The solution of the dissolved precipitate was then applied to a column of pterin-agarose [24] which had previously been equilibrated with 3 bed volumes of buffer A. The column was first washed with $50 \mathrm{ml}$ of $50 \mathrm{mM}$ Tris-acetate buffer $(\mathrm{pH} \mathrm{7.6)}$ containing $2 \mathrm{M} \mathrm{NaCl}, 2 \mathrm{mM}$ DTT and $5 \mathrm{mg}$ of catalase, followed by $20 \mathrm{ml}$ of $50 \mathrm{mM}$ Tris-acetate buffer pH 7.6 containing $0.5 \mathrm{M} \mathrm{NaCl}, 2 \mathrm{mM}$ DTT to remove the catalase and finally with $20 \mathrm{ml}$ of buffer B (10 mM sodium phosphate $(\mathrm{pH} 7.0)$ containing 
$10 \%$ glycerol, $0.06 \%$ Tween $20,50 \mu \mathrm{M}$ EDTA) to remove unbound protein. The enzyme was then eluted with $10 \mathrm{mM} \mathrm{NaHCO} / \mathrm{NaOH}$ buffer $\mathrm{pH} 10.8$ and then immediately assayed by the fluorometric determination of 5-hydroxytryptophan [25] produced from $2-10 \mu \mathrm{g}$ of protein. The active fractions were pooled and immediately adjusted to $\mathrm{pH} 7.0$ with $2 \mathrm{M}$ Tris-acetate buffer $\mathrm{pH}$ 6.4. To the pooled fractions, $\mathrm{NaCl}$, glycerol, Tween 20 and EDTA were added to a final concentration of $0.1 \mathrm{M}, 10 \%, 0.06 \%$ and 50 $\mu \mathrm{M}$, respectively, to stabilize the enzyme. The enzyme was concentrated on Filtron $30 \mathrm{~K}$ and then loaded onto a column of Sephacryl $300(1.6 \times 60$ $\mathrm{cm})$ equilibrated with buffer B. The active fractions which elute from the column after $100 \mathrm{ml}$ in a total volume of $25 \mathrm{ml}$, were pooled and concentrated on Filtron $30 \mathrm{~K}$. The enzyme was stored at $-80^{\circ} \mathrm{C}$ until needed. Protein concentrations were determined by the method of Lowry with bovine serum albumin as standard [26]. SDS-PAGE was performed with Novex (San Diego, CA) minicell precast $10 \%$ polyacrylamide gels following the procedure of Laemmli [27]. Gels were stained with FAST-STAIN (Zoion Research).

\subsection{Phosphorylation of recombinant human pineal $T P H$}

Phosphorylation of the recombinant human pineal TPH $(100 \mu \mathrm{g})$ was carried out at $30^{\circ} \mathrm{C}$ in a reaction mixture containing $50 \mathrm{mM}$ Tris-acetate $\mathrm{pH} 7.6,5 \mathrm{mM}$ $\mathrm{MgCl}_{2}, 0.1 \mathrm{mM}$ of $\mathrm{CaCl}_{2}, 0.5 \mathrm{mM}$ ATP, $0.5 \mu \mathrm{Ci}$ of $\left[\gamma_{-}{ }^{32} \mathrm{P}\right] \mathrm{ATP}, 2 \mu \mathrm{g}$ of calmodulin, and $1 \mu \mathrm{g}$ of CaMKII in a final volume of $200 \mu \mathrm{l} ; 10 \mu \mathrm{l}$ aliquots were withdrawn and the reaction was quenched at various time intervals by the addition of $10 \mu 1$ of $100 \%$ trichloroacetic acid and the resulting precipitate was collected by centrifugation. After the removal of the supernatant, the pellet was dissolved in $0.1 \mathrm{M} \mathrm{NaOH}$ and precipitated again with trichloroacetic acid. This procedure was repeated three times and the final pellets were dissolved in $0.1 \mathrm{M} \mathrm{NaOH}$ and the incorporation of radioactivity was determined. Phosphorylation of the recombinant human pineal TPH by PKA was performed as described above except that the incubation mixture contained: $50 \mathrm{mM}$ Tris-acetate $\mathrm{pH} 7.6,5 \mathrm{mM} \mathrm{MgCl}_{2}, 2 \mathrm{mM}$ DTT and $10 \mu \mathrm{g}$ of PKA.

\subsection{Measurement of activity of recombinant human pineal TPH}

Phosphorylation of TPH by either CaMKII or PKA was first stopped by the addition of $1 \mathrm{mM}$ trifluoroperazine in the case of CaMKII or with $1 \mathrm{mM}$ ATP for PKA [28] and then assayed at various time intervals for activity in a final volume of $100 \mu \mathrm{l}$. The standard assay mixture contained: $50 \mathrm{mM}$ of Tris-acetate $\mathrm{pH} 7.6$, DTT $2 \mathrm{mM}$, catalase $50 \mu \mathrm{g}$, tryptophan $250 \mu \mathrm{M}$, ferrous ammonium sulfate 0.1 $\mathrm{mM}$, glucose 6-phosphate $20 \mathrm{mM}$, NADH $2 \mathrm{mM}$, excess of glucose-6-phosphate dehydrogenase and DHPR; the reaction was initiated by the addition of $250 \mu \mathrm{M} \mathrm{BH}$. The concentration of $\mathrm{BH}_{4}$ utilized in these experiments did not show any substrate inhibition; inhibition was observed at concentrations of $\mathrm{BH}_{4}>500 \mu \mathrm{M}$. The reactions were quenched at various time intervals by the addition of $70 \%$ perchloric acid. After the removal of the resulting precipitate by centrifugation, 5-hydroxytryptophan was measured fluorometrically [25]. The assays were performed in the presence and absence of $10 \mu \mathrm{g}$ of 14-3-3 protein.

\subsection{High pressure gel filtration}

HPLC was carried out as described by Kowlessur et al. [29]. The gel filtration column (TSK-Gel G3000 SW column, $0.75 \times 50 \mathrm{~cm})$ was equilibrated with buffer B. The protein samples $(0.4-0.6 \mathrm{mg} / \mathrm{ml})$ were applied in a volume of $50-60 \mu \mathrm{l}$ at a flow rate of 0.5 $\mathrm{ml} / \mathrm{min}$ at $25^{\circ} \mathrm{C}$. The column was calibrated with a HPLC molecular weight marker protein kit supplied by US Biochemical Corporation which contains: glutamate dehydrogenase $\left(M_{\mathrm{r}} 290000\right)$, lactate dehydrogenase $\left(M_{\mathrm{r}} 142000\right)$, enolase $\left(M_{\mathrm{r}} 92000\right)$, myokinase $\left(M_{\mathrm{r}} 32000\right)$ and cytochrome $\left(M_{\mathrm{r}} 12400\right)$.

\subsection{Chromatofocusing}

Purified TPH was run on Mono P HR 5/5 (Pharmacia Biotech) for chromatofocusing. The starting buffer, pH 9.4, containing $0.025 \mathrm{mM}$ ethanolamine/ acetic acid was used followed by the eluent (Polybuffer 96-acetic acid, Pharmacia Biotech). The elution of TPH was monitored at $280 \mathrm{~nm}$. 


\section{9. $4 \alpha$-Carbinolamine dehydratase assay}

The oxidation of tetrahydrobiopterin by tryptophan hydroxylase was monitored at $245 \mathrm{~nm}$ for $4 \alpha-$ carbinolamine formation [30-32]. The complete assay mixture contained $30 \mathrm{mM}$ potassium buffer $\mathrm{pH} 8.3$, catalase $(100 \mu \mathrm{g} / \mathrm{ml}), 10 \mathrm{mM}$ glucose 6-phosphate, $2 \mu \mathrm{M}$ NADH, $600 \mu \mathrm{g}$ of TPH, $20 \mu \mathrm{M}$ tryptophan, and an excess of dihydropteridine reductase and glucose-6-phosphate dehydrogenase. The reaction was started with the addition of $20 \mu \mathrm{M} \mathrm{BH}$. When the absorbance at $245 \mathrm{~nm}$ reached a maximum, dehydratase $(5 \mu \mathrm{g} / \mathrm{ml})$ was added to the reaction mixture.

\subsection{Other methods}

The oxidation of NADH was monitored at $340 \mathrm{~nm}$ with the use of a Cary 1E spectrophotometer that was attached to a temperature controller. An extinction coefficient of $62220 \mathrm{M}^{-1} \mathrm{~cm}^{-1}$ was used to calculate the amount of NADH oxidized. All measurements were corrected for any non-enzymatic oxidation of the tetrahydropterins. Except where indicated, reactions were started by the addition of the tetrahydropterins. Spectra were recorded with a Cary $1 \mathrm{E}$ spectrophotometer equipped with a temperature controller or with a diode array Hewlett Packard spectrophotometer model 8453 attached to a temperature controller Hewlett Packard model 89090A.

\subsection{Miscellaneous methods}

$4 \alpha$-Carbinolamine dehydratase was purified by the method of Huang et al. [33]. Iron analysis was performed by a published procedure [34].

\subsection{Data analysis}

Kinetic data were analyzed to fit the following equation

$v=V /\left[1+\left(K_{\mathrm{m}} / S^{n}\right)+\left(S^{n} / K_{\mathrm{is}}\right)\right]$

where $V$ is the maximum velocity, $K_{\mathrm{m}}$ is the apparent binding constant for the substrate, $n$ is the index of cooperativity and $K_{\text {is }}$ accounts for substrate inhibition. Kinetic parameters were computed by fitting experimental data by direct fit to the MichaelisMenten equation with the Ultrafit Version 2.1, a non-linear curve fitting program with statistical analysis for the Apple Macintosh (BIOSOFT, Cambridge, UK) and with SigmaPlot, a scientific graphic program from Jandel Scientific.

\section{Results}

\subsection{Isolation of a $\mathrm{cDNA}$ clone encoding the $50 \mathrm{kDa}$ subunit of human pineal tryptophan hydroxylase from human pineal gland cDNA library}

A polymerase chain reaction approach was used to clone the target cDNA. Template DNA mix was prepared from an amplified pineal cDNA library as described in Section 2. Two oligonucleotides, which correspond to the $\mathrm{COOH}$ - and $\mathrm{NH}_{2}$-terminal encoding regions of $50 \mathrm{kDA}$ of the pineal cDNA of TPH, respectively, were utilized as primers. The polymerase reaction, designed to amplify the entire open reading frame encoding the $50 \mathrm{kDa}$ subunit, was carried out as described in Section 2. The reaction conditions for the polymerase chain reaction are similar to the condition published previously [12] except that annealing condition was raised from $40^{\circ} \mathrm{C}$ to $45^{\circ} \mathrm{C}$. Agarose gel electrophoresis analysis of the PCR product revealed that a single major band was present with the predicted size of $1.2-1.35 \mathrm{~kb}$.

In order to confirm the identity of the target DNA, several PCR products were isolated. The PCR product was purified and digested with selected restriction enzymes and then sequenced. The results indicate that the restriction patterns and the sequence data were in agreement with the published sequence of cDNA for TPH from carcinoid tissue [1]. Searches of the protein data bases using the entire 444 amino acids of pineal TPH revealed significant $(>30 \%)$ identity among the aromatic pterin-dependent hydroxylases. Furthermore, the protein that displayed the highest level of sequence identity $(100 \%)$ with the full length sequence of the pineal TPH was the TPH from carcinoid tissue. Other highly homologous proteins (and their degree of identity to human pineal gland TPH) determined from searches of the SWISSProtein data base using the FASTA search include carcinoid tissue (100\% identity), human brainstem (96\% identity), rabbit pineal gland (95\% identity), rat pineal gland (91\% identity) and mouse mastocy- 


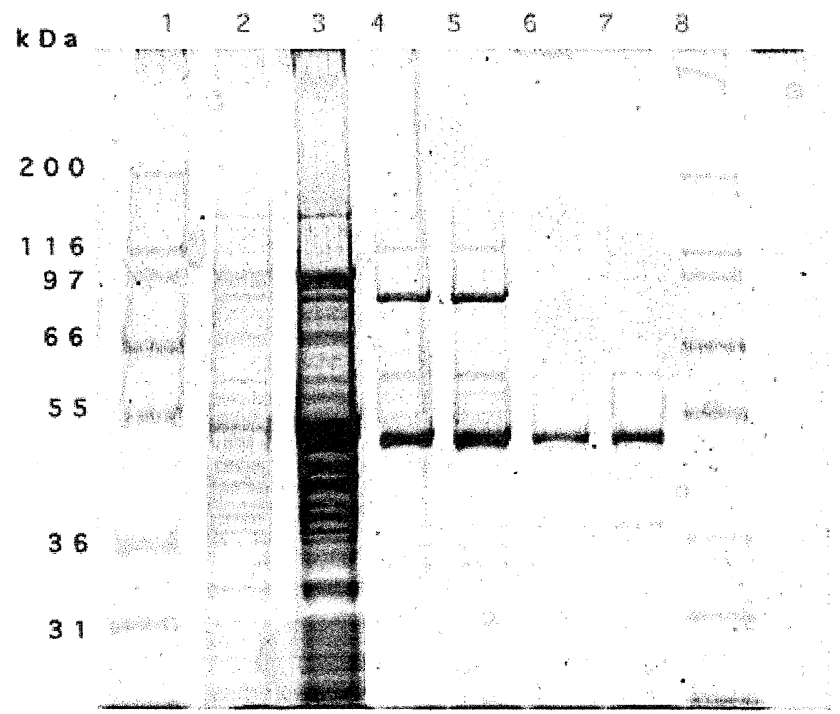

Fig. 1. SDS-PAGE of recombinant pineal TPH. Reduced samples of crude extract (lanes 2 and 3); lanes 3 and 4 contain TPH purified from the pterin-agarose column, lanes 6 and 7 contain samples from Sephacryl 300 which were run on precast $10 \%$ SDS-polyacrylamide gel (Novex) and the protein stained with Coomassie blue (Zoion). The molecular weight markers are loaded in lanes 1 and 7 .

toma cells ( $90 \%$ identity). Furthermore, the PCR product was digested with $N d e \mathrm{I}$ and $B a m \mathrm{HI}$, and subcloned into the NdeI and BamHI sites of plasmid pET20b resulting in pDKTPH. DNA sequence analysis of a strand of pDKTPH revealed that the plasmid contained the full cDNA of human pineal TPH.

The enzyme was estimated to be $90 \%$ pure by analysis on a SDS-polyacrylamide gel (Fig. 1). The molecular mass of the cloned TPH (monomer) was estimated to be $50 \mathrm{kDa}$, a value that is the same as that reported for the human enzyme [12]. When the pure protein was assayed with $(6 R)-\mathrm{BH}_{4}$, it had a specific activity of $600 \mathrm{nmol} / \mathrm{min} / \mathrm{mg}$; a similar value was obtained when the enzyme was assayed with
$6 \mathrm{MPH}_{4}$. The overall purification is summarized in Table 1. Table 1 shows that the total recovery of the enzyme units is about 7-10 times higher than the starting enzyme units. This discrepancy may be due to unknown endogenous inhibitors of tryptophan hydroxylase in the crude extract and the ammonium sulfate purification steps. To circumvent the notorious instability of TPH, we attempted to devise an isolation procedure that uses the fewest possible steps. Moreover, during all the purification steps, we included a non-ionic detergent, glycerol and protease inhibitors. In our experience, we found that the hydroxylase is stable in the presence of a non-ionic detergent and glycerol. The oligomeric composition of the pineal recombinant enzyme was determined by high pressure gel filtration on an HPLC column as described in Section 2. The molecular weight of the enzyme was calculated from a plot of molecular weights of the standards against the retention time. The molecular weight of the enzyme was estimated to be $200000 \pm 10000$, corresponding to tetramers with a retention time of $24 \mathrm{~min}$ (data not shown). The purified enzyme contains between 0.2 and $0.3 \mathrm{~mol}$ of iron per mol of TPH.

\subsection{Kinetic properties of the recombinant human pineal TPH}

A kinetic analysis of the activity of the recombinant pineal TPH with tryptophan and phenylalanine as substrates was carried out to compare them to published values obtained with human brainstem and carcinoid TPH. The kinetic parameters of the recombinant TPH are summarized in Table 2. The recombinant $\mathrm{TPH}$ has similar $K_{\mathrm{m}}\left(S_{0.5}\right)$ values for tryptophan as those reported for the recombinant brainstem TPH when assayed in the presence $\mathrm{BH}_{4}$ or $6 \mathrm{MPH}_{4}$ [12]. The rates of hydroxylation of tryp-

Table 1

Purification of cloned pineal human recombinant tryptophan hydroxylase expressed from E. coli

\begin{tabular}{llccc}
\hline Purification steps & Protein $(\mathrm{mg})$ & Activity (units) & Specific activity (units/mg) & Purification (fold) \\
\hline Extract & 435 & 195.7 & 0.45 & 1 \\
Ammonium sulfate & 186 & 209.3 & 1.13 & 2.5 \\
Pterin-agarose & 6.7 & 1485 & 222 & 50 \\
Sepharose & 3.45 & 2140 & 620 & 138
\end{tabular}

One unit of enzyme is defined as the amount of enzyme that produces $1 \mathrm{nmol}$ of 5 -hydroxytryptophan per min at $37^{\circ} \mathrm{C}$. 
tophan in the presence of either $\mathrm{BH}_{4}$ or $6 \mathrm{MPH}_{4}$ are very similar when assayed under $V_{\max }$ conditions (data not shown). The values for the $K_{\mathrm{m}}$ of tryptophan when assayed in the presence of either $\mathrm{BH}_{4}$ or $6 \mathrm{MPH}_{4}$ are similar except that, in confirmation of our previous finding [35], substrate inhibition was observed when the concentration of tryptophan was greater than $0.2 \mathrm{mM}$ in the presence of $\mathrm{BH}_{4}$ as cofactor. Substrate inhibition was also observed with Lphenylalanine at concentrations greater than 0.045 M. Phenylalanine behaves as a competitive inhibitor towards tryptophan with a calculated $K_{\mathrm{i}}$ value of 150 $\mu \mathrm{M}$ (Fig. 2), a value that is somewhat lower than the $K_{\mathrm{i}}$ of $197 \mu \mathrm{M}$ found for the rabbit hind brain enzyme [35].

It has been reported that partially purified TPH from beef pineal gland can hydroxylate phenylalanine in the presence of $\mathrm{DMPH}_{4}$ [36] and that the partially purified enzyme from rabbit hind brain can hydroxylate phenylalanine in the presence of $\mathrm{BH}_{4}$ [35]. With the recombinant human TPH, the rate of hydroxylation of phenylalanine in the presence of $\mathrm{BH}_{4}$ was found to be comparable to that of tryptophan (data not shown). However, their $K_{\mathrm{m}}$ val-

Table 2

Michaelis-Menten parameters for tryptophan hydroxylation by recombinant human pineal tryptophan hydroxylase with $\mathrm{BH}_{4}$, $6 \mathrm{MPH}_{4}$, and $7 \mathrm{BH}_{4}$ as cofactors

\begin{tabular}{lcl}
\hline Cofactor & $\begin{array}{l}K_{\mathrm{m}} \text { (cofactor) } \\
(\mu \mathrm{M})\end{array}$ & $\begin{array}{l}K_{\mathrm{m}} \text { (tryptophan) } \\
(\mu \mathrm{M})\end{array}$ \\
\hline$(6 R)-\mathrm{BH}_{4}$ & 45 & $20^{\mathrm{a}}$ \\
$6 \mathrm{MPH}_{4}$ & 75 & 23 \\
$(7 R)-\mathrm{BH}_{4}$ & 2100 & $\mathrm{ND}$ \\
$(6 R)-\mathrm{BH}_{4}$ & $\mathrm{ND}$ & $90^{\mathrm{a}, \mathrm{b}}$ \\
\hline
\end{tabular}

The apparent $K_{\mathrm{m}}$ values were determined as described in Section 2.2. All experimental data were processed by computer fit to the Michaelis-Menten equation.

ND, not determined.

${ }^{\mathrm{a}} K_{\mathrm{m}}$ shown in the table was determined from $S_{0.5}$ (the halfmaximal substrate concentration) where calculation of a true $K_{\mathrm{m}}$ was prevented due to substrate inhibition.

${ }^{\mathrm{b}} K_{\mathrm{m}}$ for phenylalanine shown in the table was determined from $S_{0.5}$ (the half-maximal substrate concentration of phenylalanine). The concentration of (6R)- $\mathrm{BH}_{4}$ used for $K_{\mathrm{m}}$ determination was $250 \mu \mathrm{M}$. All of the measurements were carried out in triplicate; the standard deviation was about $10 \%$ of the measured value. The determination of $K_{\mathrm{m}}$ values for the amino acid substrates were carried out at fixed, saturating concentrations of $\mathrm{BH}_{4}$ and $6 \mathrm{MPH}_{4}$.

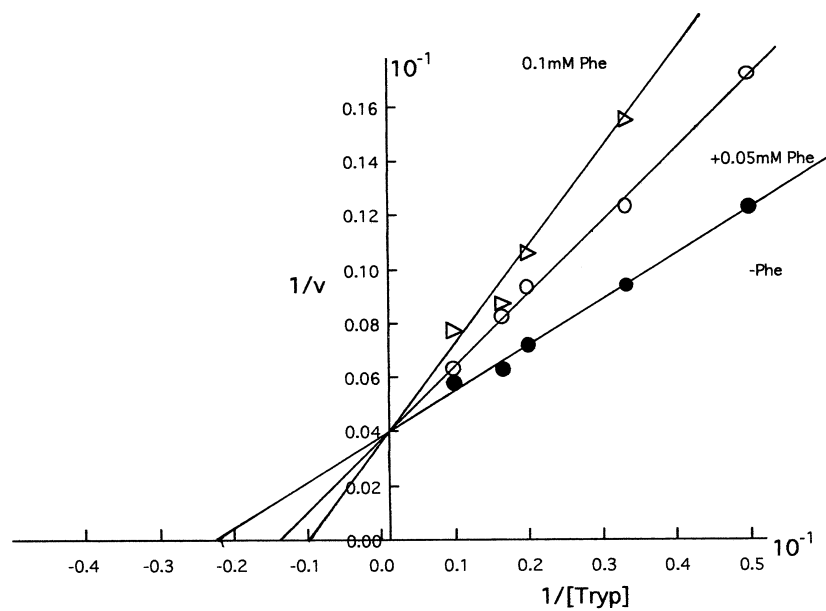

Fig. 2. Reciprocal plot of rate versus substrate concentration. Assay conditions are described in Section 2. The concentration of $\mathrm{BH}_{4}$ in the assay was $0.2 \mathrm{mM}$ and that of TPH was $20 \mu \mathrm{g} /$ $\mathrm{ml}$; the concentrations of phenylalanine were $50 \mu \mathrm{M}$ and 100 $\mu \mathrm{M}$. The rates are expressed as nmol of 5-hydroxytryptophan/ $\mathrm{min} / \mathrm{mg}$.

ues differ, the $K_{\mathrm{m}}$ for tryptophan being less than onefourth that for phenylalanine (Table 2). It has also been reported that $7 \mathrm{BH}_{4}$ is a less efficient cofactor for rabbit brain TPH [37] and that it is also a poor inhibitor of rabbit brain TPH in the presence of $\mathrm{BH}_{4}$. In the presence of $0.15 \mathrm{mM}$ tryptophan, the rate of the TPH catalyzed hydroxylation of tryptophan to 5-hydroxytryptophan with $7 \mathrm{BH}_{4}$ is only $16 \%$ that of $\mathrm{BH}_{4}$. In good agreement with our previous value of $1.7 \mathrm{mM}$ for the rabbit brain TPH [37], the apparent $K_{\mathrm{m}}$ for $7 \mathrm{BH}_{4}$ for the recombinant pineal enzyme is $2.1 \mathrm{mM}$, almost 50 -fold higher than that of $\mathrm{BH}_{4}$ (Table 2). The $K_{\mathrm{m}}$ for tryptophan with $7 \mathrm{BH}_{4}$ as the cofactor could not be determined due to the low rate of hydroxylation and significant substrate inhibition at tryptophan concentrations greater than $0.15 \mathrm{mM}$. An $\mathrm{IC}_{50}$ of $2.1 \mathrm{mM}$ for $7 \mathrm{BH}_{4}$ was calculated when the enzyme was assayed in the presence of $0.15 \mathrm{mM}$ tryptophan and $0.1 \mathrm{mM} \mathrm{BH}_{4}$. Various tryptophan derivatives were also examined for their inhibitory effect. The end products of the biosynthetic pathway or their metabolites, serotonin and melatonin, did not inhibit at concentrations as high as $1 \mathrm{mM}$. L-5-Hydroxytryptophan was the only naturally occurring compound that inhibits the enzyme with an inhibition constant of $35 \mu \mathrm{M}$ (data not shown). 
A
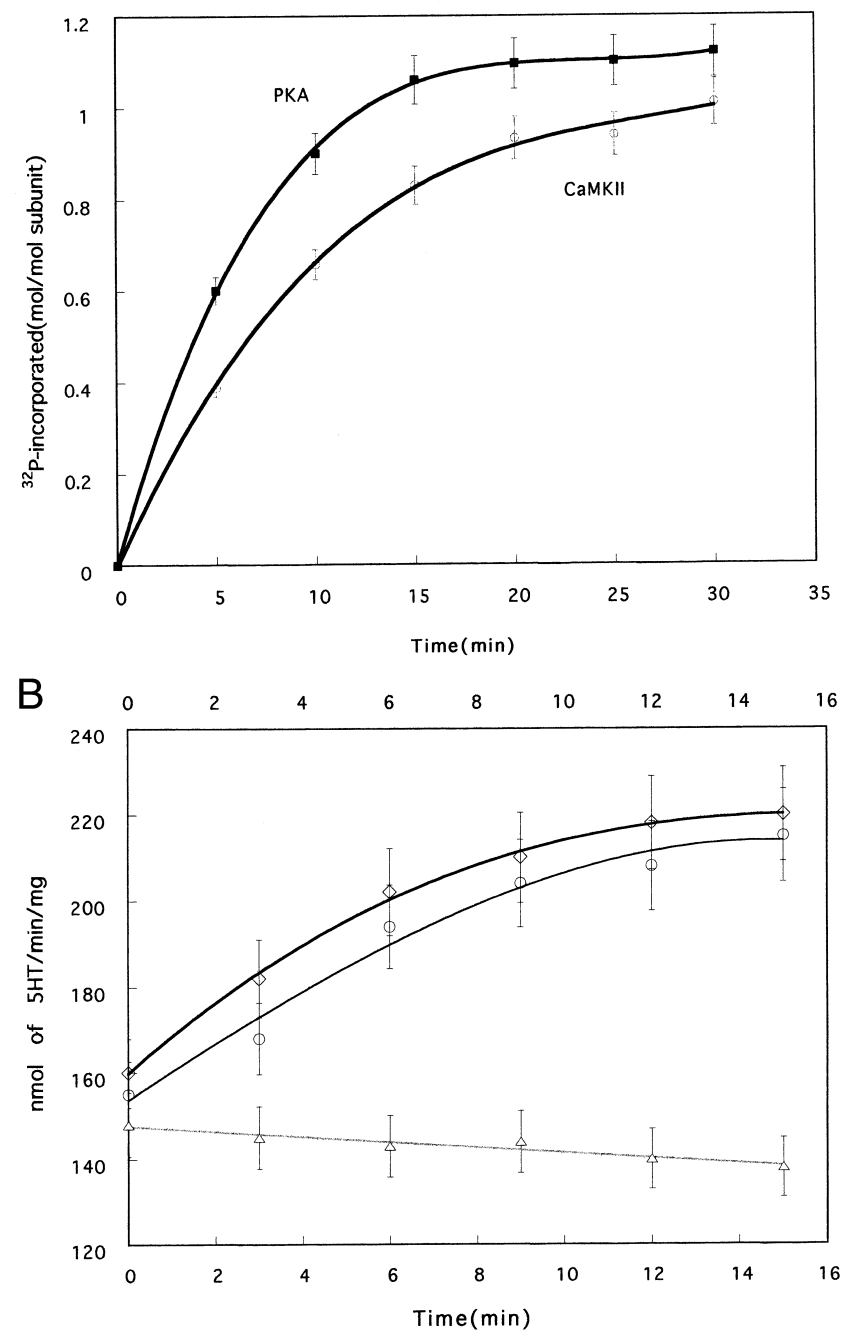

Fig. 3. (A) Time course of phosphorylation of recombinant pineal TPH with $\left[\gamma^{32} \mathrm{P}\right] \mathrm{ATP}$. TPH $(12 \mu \mathrm{g})$ was phosphorylated by either calmodulin-dependent kinase II from rat brain $(0.5$ $\mu \mathrm{g})$ or cAMP-dependent protein kinase $(1 \mu \mathrm{g})$. Phosphorylation of TPH was carried out in a reaction mixture $(50 \mathrm{mM}$ Tris$\mathrm{HCl}, \mathrm{pH} 7.6,5 \mathrm{mM} \mathrm{MgCl}_{2}, 0.1 \mathrm{mM} \mathrm{CaCl} 2,0.5 \mathrm{mM}$ ATP, 0.5 $\mu \mathrm{Ci}$ of $\gamma-{ }^{32} \mathrm{P}, 2 \mu \mathrm{g}$ calmodulin and $1 \mu \mathrm{g}$ CaMKII) and in the absence of $14-3-3$ in a final volume of $200 \mu$ l. The reaction was performed at $30^{\circ} \mathrm{C}$. Phosphorylation of TPH by PKA was carried out as described above except that the reaction mixture contained $2 \mathrm{mM}$ dithiothreitol and $1 \mu \mathrm{g}$ of PKA. Data are mean \pm S.E.M. (error bars) values of triplicate assays. (B) Activation of phosphorylated pineal TPH by 14-3-3. Effect of the recombinant bovine brain 14-3-3 (10 $\mu \mathrm{g})$ ( $\zeta$ forms) on the activity of phosphorylated pineal TPH. Control experiments were carried out with a complete assay system without CaMKII or PKA. $\triangle$, activity of TPH phosphorylated by either PKA or CAMKII in the absence of 14-3-3; $\diamond$, activity of TPH phosphorylated by PKA in the presence of 14-3-3; $O$, activity of TPH phosphorylated by CAMKII in the presence of 14-3-3. Data are means \pm S.E.M. of two experiments carried out in triplicate. $\leftarrow$

\subsection{The stoichiometry of tryptophan-dependent oxidation of tetrahydrobiopterin catalyzed by TPH}

It has been reported previously that the stoichiometry of the conversion of tryptophan to 5-hydroxytryptophan catalyzed by partially purified TPH isolated from rabbit hind brain is tightly coupled with a ratio of hydroxylated product formed to the tetrahydropterin oxidized being about 0.95 in the presence of a mixture of the synthetic diastereoisomers of $\mathrm{BH}_{4}$ [25], 6 $\mathrm{MPH}_{4}$ [35] and $\mathrm{DMPH}_{4}$ [35]. As can be seen in Table 3 , the reaction catalyzed by the recombinant

Table 3

Stoichiometry of the tryptophan-dependent oxidation of tetrahydropterins catalyzed by recombinant human pineal tryptophan hydroxylase

\begin{tabular}{lllll}
\hline Cofactor & $5-\mathrm{HTP}(\mathrm{nmol})$ formed & NADH $(\mathrm{nmol})$ oxidized & 5-HTP/NADH average & \% coupled \\
\hline $6(R)-\mathrm{BH}_{4}$ & $5.02,6.51$ & $6.06,7.01$ & 0.88 & 88 \\
$6(R, S)-\mathrm{MPH}_{4}$ & $4.03,6.05$ & $5.02,6.22$ & 0.89 & 89 \\
$7(R, S)-\mathrm{BH}_{4}$ & $0.92,1.23$ & $5.01,6.04$ & 0.18 & 18 \\
$6(S)-\mathrm{BH}_{4}$ & $1.22,1.51$ & $6.04,5.51$ & 0.24 & 24 \\
\hline
\end{tabular}

The reaction mixtures contained: recombinant human pineal TPH $(2 \mu \mathrm{g}), 0.1 \mathrm{M}$ Tris- $\mathrm{HCl} \mathrm{pH} 7.5,250 \mu \mathrm{M}$ L-tryptophan, $2 \mathrm{mM}$ DTT, $2 \mathrm{mM} \mathrm{NADH}$, catalase $0.1 \mathrm{mg} / \mathrm{ml}, 2$ units dihydropteridine reductase. The reaction was started by the addition of $0.2 \mathrm{mM}$ tetrahydropterin. The tryptophan-dependent oxidation of NADH was followed at $340 \mathrm{~nm}$ and allowed to proceed for 10 min. The reaction was then quenched by the addition of $100 \mu \mathrm{l}$ of $70 \%$ perchloric acid. The amount of NADH oxidized and 5-HTP produced was quantified as described in Section 2. The listed values in the table reflect the amounts of products formed after 10 min of reaction. Note: In the presence of excess DHPR, the amount of NADH oxidized is equal to the amount of tetrahydrobiopterin oxidized [57]. 
human pineal enzyme in the presence of the naturally occurring $R$-diastereoisomer of $\mathrm{BH}_{4}$, as well as in the presence of the mixture of $R$ and $S$ isomers of $6 \mathrm{MPH}_{4}$, are quite tightly coupled (average ratio 0.88 and 0.89 , respectively). By contrast, in the presence of either $(7 R, S)-\mathrm{BH}_{4}$ or $(6 S)-\mathrm{BH}_{4}$, the unnatural isomer of $\mathrm{BH}_{4}$, the hydroxylation of tryptophan is largely uncoupled from the oxidation of the tetrahydrobiopterin (average ratio 0.18 and 0.24 , respectively). The extent of uncoupling in the presence of $(7 R, S)-\mathrm{BH}_{4}$ is about the same as was previously observed with rat liver PAH (ratio $=0.17)$ [38]. As can be seen (Table 3), when measured as the rate of $\mathrm{NADH}$ oxidation, the activity of the $(6 S)-\mathrm{BH}_{4}$ isomer is comparable to that of the $6 R$ isomer. By contrast, because of the uncoupling, the rate of formation of 5-hydroxytryptophan with $(6 S)-\mathrm{BH}_{4}$ is only about one-fourth that observed with the $6 R$ isomer. Even this relatively slow activity, however, is higher than that reported for the $6 S$ isomer with crude rat brain $\mathrm{TPH}$, where it was found to be only $10 \%$ as active as $(6 R)-\mathrm{BH}_{4}[39]$.

\subsection{The stoichiometry of phosphorylation and its influence on the catalytic properties of the pineal $T P H$}

Covalent modification of the human TPH by phosphorylation mediated by PKA and CaMKII was carried out to investigate whether the hydroxylase is activated by phosphorylation and whether the effect is dependent on the presence of 14-3-3. Treatment of the enzyme with either PKA or CaMKII and $\left[\gamma^{32} \mathrm{P}\right] \mathrm{ATP}$ led to the incorporation of about $1.0 \mathrm{~mol}$ of $\left[{ }^{32} \mathrm{P}_{\mathrm{i}}\right]$ phosphate per mol of subunit (Fig. 3A). It has been reported that 14-3-3 enhances the activity of TPH that has been phosphorylated by either PKA or CaMKII, whereas non-phosphorylated TPH is not activated in the presence of 14-3-3 [28]. As can be seen in Fig. 3B, the addition of 14-3-3 to the TPH assay mixture (see Section 2) resulted in an about $45 \%$ increase of activity of the enzyme that had been phosphorylated with either CaMKII or PKA. Since incubation of TPH in the absence of the kinase results in an about 10\% loss in activity (Fig. 3B), the stimulation by 14-3-3 is somewhat greater when compared to the activity in the controls. However, it is calculated that the stimulation is less than the $100 \%$ in activation mediated by 14-3-3 that was reported for the rat brainstem TPH [28].

\subsection{Formation of carbinolamine during the enzymatic conversion of tryptophan to 5-hydroxytryptophan by TPH and the effect of $4 \alpha$-carbinolamine dehydratase on TPH activity}

During the course of PAH-catalyzed oxidation of tetrahydrobiopterin, either coupled or uncoupled to hydroxylation of phenylalanine, the formation of a pterin $4 \alpha$-carbinolamine has been detected by ultraviolet spectroscopy $[31,40]$. The generation of the $4 \alpha-$ carbinolamine as a transient spectroscopic species by tyrosine hydroxylase using tyrosine or phenylalanine as a substrate has also been reported [41]. Recently, formation of the $4 \alpha$-carbinolamine has also been demonstrated with the catalytic core of rabbit TPH (TPH 102-416) [16]. Using rapid scanning ultraviolet spectroscopy, we have also detected the formation of $4 \alpha$-carbinolamine during the pineal TPH-catalyzed hydroxylation of phenylalanine (data not shown) and tryptophan using the intact hydroxylase. As can be seen in Fig. 4A, the ultraviolet spectral changes that occur during the TPH-catalyzed hydroxylation of tryptophan in the presence of $\mathrm{BH}_{4}$ are consistent with the rapid formation of the $4 \alpha-$ pterin carbinolamine, whose most characteristic spectral feature is a pronounced peak centered at $245 \mathrm{~nm}$ [31]. Further evidence in support of the conclusion that the observed spectral changes represent those due to the formation of the carbinolamine was obtained in studies of the effect of the addition of dehydratase (also designated 'PHS' for phenylalanine hydroxylase stimulator) on the characteristic 245 $\mathrm{nm}$ peak. As shown in Fig. 4B, the addition of pure dehydratase to a reaction mixture in which the formation of the putative carbinolamine has reached a steady state leads to the rapid disappearance of the $245 \mathrm{~nm}$ peak, an effect coherent with the dehydratase-catalyzed conversion of the carbinolamine to the corresponding quinonoid dihydropterin derivative [31]. Under these conditions, dehydratase was found to stimulate TPH activity in a concentration-dependent manner with maximum stimulation being about 1.5 -fold (Fig. 4C). 
Fig. 4. (A) The formation of the $4 \alpha$-carbinolamine during the tryptophan-dependent coupled oxidation of tetrahydrobiopterin by recombinant human pineal tryptophan hydroxylase. Spectra were monitored from $235 \mathrm{~nm}$ to $350 \mathrm{~nm}$. The final concentrations of the reagents were: $20 \mathrm{mM}$ potassium phosphate $\mathrm{pH}$ $8.3,20 \mu \mathrm{M} \mathrm{BH}_{4}, 50 \mu \mathrm{g} / \mathrm{ml}$ of catalase, $10 \mu \mathrm{M}$ tryptophan, 100 $\mu \mathrm{M}$ ferrous ammonium sulfate, $600 \mu \mathrm{g} / \mathrm{ml}$ of recombinant $\mathrm{TPH}$. The reactions were followed at $10^{\circ} \mathrm{C}$ and initiated by the addition of $20 \mu \mathrm{M} \mathrm{BH}$. Immediately after the final addition of $\mathrm{BH}_{4}$, the spectra were recorded at the following times: curve C, $10 \mathrm{~s}$; curve $\mathrm{B}, 15 \mathrm{~s}$. (Curve $\mathrm{A}$ is the spectrum of $\mathrm{BH}_{4}$.) (B) The effect of $4 \alpha$-carbinolamine dehydratase activity on $4 \alpha$-carbinolamine generated by recombinant human pineal TPH. The oxidation of $\mathrm{BH}_{4}$ by human pineal recombinant $\mathrm{TPH}$ at $10^{\circ} \mathrm{C}$ was monitored at $245 \mathrm{~nm}$. At the time shown, $20 \mu \mathrm{g} / \mathrm{ml}$ of PHS was added to the reaction mixtures. The reaction mixture contained the following components: $20 \mathrm{mM}$ potassium phosphate, $\mathrm{pH}$ 8.3, $10 \mu \mathrm{M}$ tryptophan, $50 \mu \mathrm{g} / \mathrm{ml}$ catalase, $20 \mathrm{mM}$ glucose 6phosphate, $10 \mu \mathrm{M}$ of NADH and excess of both glucose-6phosphate dehydrogenase and dihydropteridine reductase; the reaction was started by the addition of $20 \mu \mathrm{M} \mathrm{BH}_{4}$. (C) The effect of the concentration of PHS on the activity of human pineal recombinant TPH. The assay mixtures contained: $50 \mathrm{mM}$ of Tris-acetate $\mathrm{pH} 7.6$, DTT $2 \mathrm{mM}$, catalase $50 \mu \mathrm{g}$, tryptophan $250 \mu \mathrm{M}$, ferrous ammonium sulfate $0.1 \mathrm{mM}$, glucose 6-phosphate $20 \mathrm{mM}$, NADH $2 \mathrm{mM}$, TPH $5 \mu \mathrm{g}$, and excess of glucose-6-phosphate dehydrogenase and DHPR; the reaction was initiated by the addition of $250 \mu \mathrm{M} \mathrm{BH} 4$. After $15 \mathrm{~min}$ the reactions were quenched by the addition of $70 \%$ perchloric acid and after centrifugation, the concentration of 5-hydroxytryptophan was determined in the supernatant as described in Section 2.2. - reaction mixtures to which various concentrations of PHS were added; $\boldsymbol{\square}$, control reaction mixtures from which PHS was omitted.

\section{Discussion}

In this paper we describe the cloning and expression of a cDNA encoding recombinant human pineal TPH and present an analysis of some of the catalytic and regulatory properties of the recombinant enzyme. We chose to utilize a PCR approach using the primers designed as described in Section 2. The PCR products revealed the entire coding sequence of the human pineal TPH which is identical to the published sequence from human carcinoid tissue [1]. The resulting cDNA was cloned into pET20b+ plasmid in the multiple cloning sites containing NdeI and BamHI. This strategy ensures the introduction of the TPH cDNA into the proper orientation for expression. The sequence predicts a subunit of TPH consisting of 444 amino acids, with molecular mass of
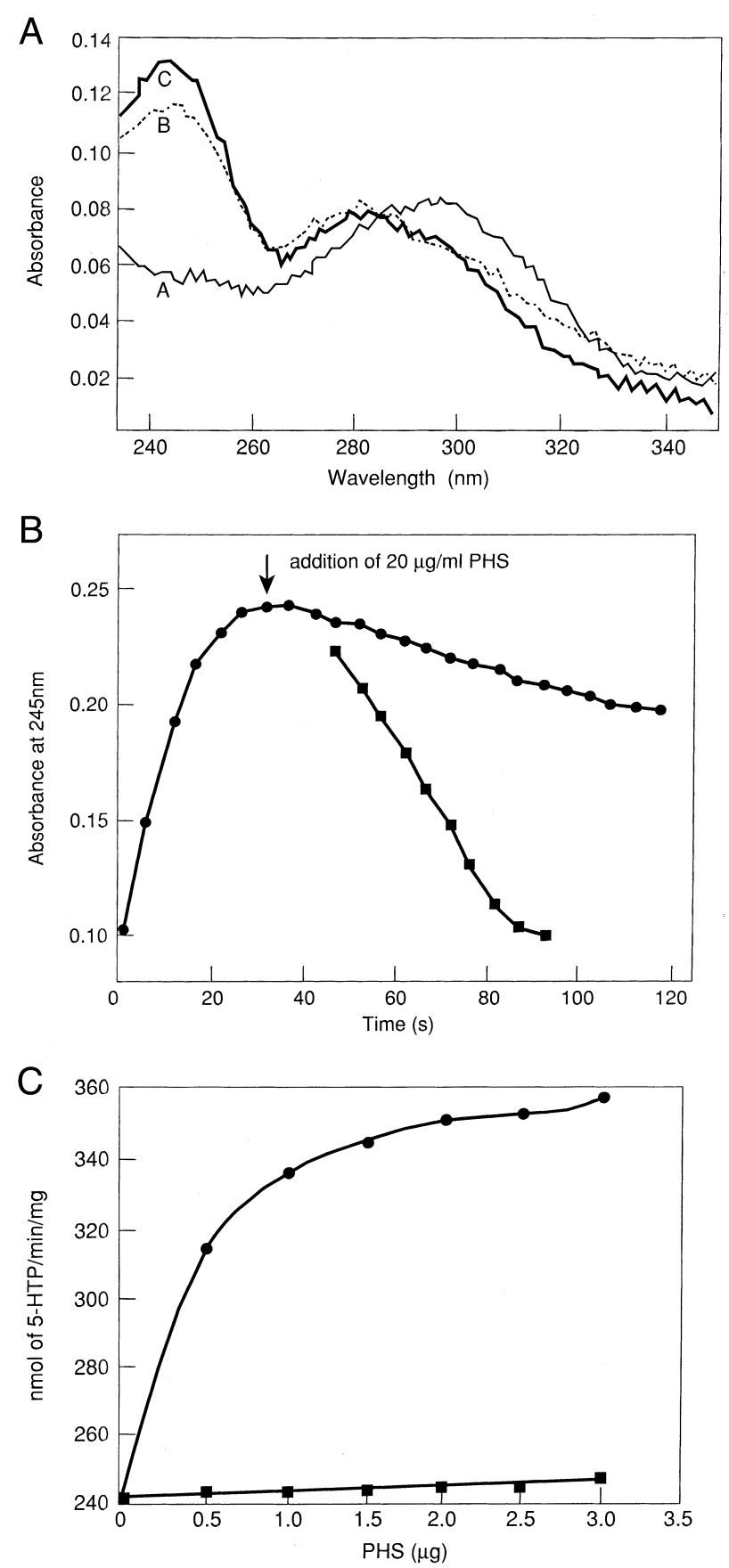

$51000 \mathrm{kDa}$ and a calculated $\mathrm{p} I$ of 7.19 , in reasonable agreement with our experimentally determined value of $\mathrm{p} I$ of 7.4-7.6 (data not shown).

The purification scheme presented in this study resulted in a preparation of TPH with a specific activity 3-4-fold higher than those obtained in previous studies $[12,14]$. The high degree of purity may be 
explained by the inclusion of a purification step in which TPH is adsorbed to and eluted from a pterinagarose column [23] (Table 1). The $M_{\mathrm{r}}$ of approx. $200000 \pm 10000$ found in this study is similar to the $M_{\mathrm{r}}$ of 200000 reported previously [35,42]. The apparent $K_{\mathrm{m}}$ values of the purified recombinant human pineal TPH are $45 \mu \mathrm{M}$ for $\mathrm{BH}_{4}$ and $74 \mu \mathrm{M}$ for $6 \mathrm{MPH}_{4}$, when assayed in the presence of tryptophan. The $K_{\mathrm{m}}$ for $\mathrm{BH}_{4}$ is one-third lower than the value reported for the recombinant human brain TPH [12]. The apparent $K_{\mathrm{m}}$ values of recombinant pineal TPH were $20 \mu \mathrm{M}$ and $23 \mu \mathrm{M}$ for tryptophan when assayed in the presence of $\mathrm{BH}_{4}$ and $6 \mathrm{MPH}_{4}$ respectively. It should be noted that these $K_{\mathrm{m}}$ values are similar to the reported fasting concentration of tryptophan in plasma of $0.030 \pm 0.002 \mathrm{mM}$ [43]. Corresponding values of 8 and $7 \mu \mathrm{M}$, respectively, have been reported earlier [12]. Our values indicate that pineal TPH may have a 2-fold lower affinity for tryptophan than does recombinant brain TPH. In comparison, the $K_{\mathrm{m}}$ values reported for the native human brain enzyme were $142 \mu \mathrm{M}$ for tryptophan when assayed in the presence of $6 \mathrm{MPH}_{4}$ [44] and $13 \mu \mathrm{M}$ for tryptophan for TPH from human carcinoid tumor when assayed in the presence of $6 \mathrm{MPH}_{4}$ [45]. In this respect, the recombinant human pineal TPH resembles the carcinoid tumor enzyme. The recombinant human pineal TPH is inhibited by phenylalanine $\left(K_{\mathrm{i}}=150 \mu \mathrm{M}\right)$, a property shared by the native rabbit brain enzyme [35]. This sensitivity to phenylalanine inhibition indicates that the elevated levels of phenylalanine, such as those seen in classical phenylketonuric patients, cannot only inhibit biogenic amine synthesis in brain [46], but may also inhibit melatonin synthesis in pineal tissue and may, therefore, attenuate some of the many physiological functions of this bioregulator [47].

Although the importance of phosphorylation of TPH in the regulation of the activity of this enzyme has long been recognized, there remain gaps in our understanding of the quantitative aspects of the regulatory mechanism, including even the stoichiometry of the reaction. On this point, values varying from approx. $0.13 / \mathrm{mol}$ of TPH subunit for the CaMKIImediated phosphorylation of rat brain TPH [48] to $0.4 \mathrm{~mol} / \mathrm{mol}$ of the recombinant rabbit brain enzyme that has been expressed in insect cells [49] have been published. There have also been several reports of the incorporation of unknown amounts of phosphate into TPH $[13,50]$.

In the current study we have shown that in the presence of either PKA or CaMKII, approx. 1.0 mol of phosphate is incorporated per mol of TPH subunit (Fig. 3A), a value that is considerably higher than those previously published. Our higher value may be due, in part, to the fact that the present enzyme, which was expressed in $E$. coli, probably contains little or no endogenously bound phosphate compared to the enzyme used in the other cited studies. It is also possible that for reasons that are not apparent the pineal enzyme differs in this respect from its brain counterpart.

Based on the amino acid sequence data, Darmon et al. [51] predicted that serine 260 and 443 are potential sites for phosphorylation by CaMKII and that serine 58 is a likely site for PKA-mediated phosphorylation. The latter prediction has recently been verified experimentally [50]. Although we have not determined the site(s) phosphorylated by either PKA or CaMKII in the present study, preliminary results based on deletion analyses indicate that serine residues 58 and 443 can both be phosphorylated by PKA as well as by CaMKII (X.-J. Yang and S. Kaufman unpublished results). Further work will be required to identify the site that is phosphorylated in the pineal TPH preparation used in the present study. We have also demonstrated that phosphorylation of the recombinant TPH by either CaMKII or PKA results in an increase in the catalytic activity of the enzyme by $45 \%$ in the presence of $14-3-3$. Nonphosphorylated TPH is not activated in the presence of 14-3-3 (see Fig. 3B). This level of activation is lower than the $85 \%$ stimulation reported by Ishimura et al. [18] with TPH purified from rat brainstem. The lower activation of the phosphorylated enzyme in the presence of 14-3-3 may also be due to the low specific activity of the recombinant 14-3-3 or to the possibility that the recombinant TPH interacts less specifically with 14-3-3.

The most common structural and biochemical features among the pterin-dependent aromatic acid hydroxylases have been extensively reviewed [52]. Based on their substrate and cofactor requirements, it has been suggested that these aromatic acid hydroxylases share a common hydroxylation mechanism [52]. The cloning of tryptophan, tyrosine and phenylalanine 
hydroxylases has revealed striking similarities in their catalytic regions. Although this similarity bolsters the conclusion that these three enzyme share a common mechanism, more biochemical evidence is required to establish this point. Following the demonstration that the carbinolamine, $4 \alpha$-hydroxytetrahydrobiopterin, is the first free pterin product that can be detected during PAH-catalyzed hydroxylation of phenylalanine [30,31], evidence was presented showing that the same compound is also formed during the TH-catalyzed hydroxylation of both phenylalanine and tyrosine [41]. Recently, carbinolamine formation has also been demonstrated during the hydroxylation of tryptophan catalyzed by the catalytic core of rabbit pineal TPH [16]. The findings provided strong support, at the biochemical level, that PAH, TH and TPH do indeed share a common mechanism.

In the present study, we have shown that with intact human pineal tryptophan hydroxylase, formation of carbinolamine can also be detected during the course of the hydroxylation of L-tryptophan (Fig. 4A). The evidence supporting this conclusion is not only that a compound is formed with the unusual spectral characteristics of the carbinolamine, in particular, a sharp absorption at $245 \mathrm{~nm}[30,32,53]$, but also that the compound is a substrate for pure $4 \alpha$ carbinolamine dehydratase (Fig. 4B).

As expected from the result shown in Fig. 4B, the addition of the dehydratase was found to stimulate the rate of hydroxylation of tryptophan. The stimulation is about 1.5 -fold (Fig. 4C). It should be noted that although this is a modest effect, it is possible that the effect in vivo would be greater. One of the uncertainties in attempting to make this extrapolation is that the stimulation of hydroxylase activity by the dehydratase has been shown to markedly increase with increasing concentrations of the hydroxylase [54]. The concentration of TPH in brain or pineal tissue, of course, is not known but it could be much higher than the concentration used in the experiment described in Fig. 4B. It should be mentioned that the finding that pineal tissue expresses relatively high dehydratase activity is also coherent with a role for the dehydratase in modulating TPH activity in vivo in this tissue [55].

The observed stimulation of TPH activity by the dehydratase may be relevant to our understanding of hyperphenylalaninemia caused by a documented ge- netic deficiency of the dehydratase [56]. The observation raises the possibility that a severe deficiency of dehydratase would lead to defects in melatonin synthesis, in addition to the defects in phenylalanine catabolism.

Based on our studies, we conclude that the biochemical and structural properties of the recombinant human pineal TPH and the human brainstem are similar, if not identical, to those of the native enzyme. The availability of the recombinant human pineal TPH in large quantities should facilitate further structural and functional characterization of human pineal TPH.

\section{Acknowledgements}

We thank Kun Park and Cynthia Falke for technical assistance.

\section{References}

[1] S. Boularand, M.C. Darmon, Y. Ganem, J.M. Launay, J. Mallet, Complete coding sequence of human tryptophan hydroxylase, Nucleic Acids Res. 18 (1990) 4257.

[2] E. Jequier, W. Lovenberg, A. Sjoerdsma, Tryptophan hydroxylase inhibition: the mechanism by which $p$-chlorophenylalanine depletes rat brain serotonin, Mol. Pharmacol. 3 (1967) 274-278.

[3] D.G. Grahame-Smith, Tryptophan hydroxylation in brain, Biochem. Biophys. Res. Commun. 16 (1964) 586-592.

[4] W. Lovenberg, E. Jequier, A. Sjoerdsma, Tryptophan hydroxylation: measurement in pineal gland, brainstem, and carcinoid tumor, Science 155 (1967) 217-219.

[5] M.D. Gershon, C.F. Dreyfus, V.M. Pickel, T.H. Joh, D.J. Reis, Serotonergic neurons in the peripheral nervous system: identification in gut by immunohistochemical localization of tryptophan hydroxylase, Proc. Natl. Acad. Sci. USA 74 (1977) 3086-3089.

[6] R.N. Golden, Serotonin in psychiatric disorders, Psychiatr. Ann. 20 (1990) 556-602.

[7] S.M. Paul, Serotonin and its effects on human behavior, Clin. Psychiatry 51 (Suppl.) (1990) 1-70.

[8] H.E. Grenett, F.D. Ledley, L.L. Reed, S.L.C. Woo, Fulllength cDNA for rabbit tryptophan hydroxylase: functional domains and evolution of aromatic amino acid hydroxylases, Proc. Natl. Acad. Sci. USA 84 (1987) 5530-5534.

[9] M.C. Darmon, B. Grima, C.D. Cash, M. Maitre, J. Mallet, Isolation of a rat pineal gland cDNA clone homologous to tyrosine and phenylalanine hydroxylases, FEBS Lett. 206 (1986) 43-46. 
[10] J. Stoll, C.A. Kozak, D. Goldman, Characterization and chromosomal mapping of a cDNA encoding tryptophan hydroxylase from a mouse mastocytoma cell line, Genomics 7 (1990) 88-96.

[11] D.H. Park, D.M. Stone, K.S. Kim, T.H. Joh, Characterization of recombinant mouse tryptophan hydroxylase expressed in Escherichia coli, Mol. Cell. Neurosci. 5 (1994) 87-93.

[12] J.P. Tipper, B.A. Citron, P. Ribeiro, S. Kaufman, Cloning and expression of rabbit and human brain tryptophan hydroxylase cDNA in Escherichia coli, Arch. Biochem. Biophys. 315 (1994) 445-453.

[13] K.E. Vrana, P.J. Rucker, S.C. Kumer, Recombinant rabbit tryptophan hydroxylase is a substrate for cAMP-dependent protein kinase, Life Sci. 55 (1994) 1045-1052.

[14] X.J. Yang, S. Kaufman, High-level expression and deletion mutagenesis of human tryptophan hydroxylase, Proc. Natl. Acad. Sci. USA 91 (1994) 6659-6663.

[15] M. Carrol, D’Sa., J.R.E. Arthur, M.D. Kuhn, Expression and deletion mutagenesis of tryptophan hydroxylase fusion proteins: delineation of the enzyme catalytic core, J. Neurochem. 67 (1996) 917-926.

[16] G.R. Moran, S.C. Daubner, P.F. Fitzpatrick, Expression and characterization of the catalytic core of tryptophan hydroxylase, J. Biol. Chem. 273 (1998) 12259-12266.

[17] T. Ichimura, T. Isobe, T. Okuyama, T. Yamauchi, H. Fujisawa, Brain 14-3-3 protein is an activator protein that activates tryptophan 5-monooxygenase and tyrosine 3-monooxygenase in the presence of $\mathrm{Ca}^{2+}$,calmodulin-dependent protein kinase II, FEBS Lett. 219 (1987) 79-82.

[18] T. Ishimura, T. Isobe, T. Okuyama, N. Takahashi, R. Araki, R. Kuwano, Y. Takahashi, Molecular cloning of cDNA coding for brain-specific 14-3-3 protein, a protein kinase-dependent activator of tyrosine and tryptophan hydroxylases, Proc. Natl. Acad. Sci. USA 85 (1988) 7084-7088.

[19] T. Isobe, T. Ichimura, T. Sunaya, T. Okuyama, N. Takahashi, R. Kuwano, Y. Takahashi, Distinct forms of the protein kinase-dependent activator of tyrosine and tryptophan hydroxylases, J. Mol. Biol. 217 (1991) 125-132.

[20] T. Ichimura, J. Uchiyama, O. Kunihiro, M. Ito, T. Horigome, S. Omata, F. Shinkai, H. Kaji, T. Isobe, Identification of the site of interaction of the 14-3-3 protein with phosphorylated tryptophan hydroxylase, J. Biol. Chem. 270 (1995) 28515-28518.

[21] J.H. Miller, Experiments in Molecular Genetics, Cold Spring Harbor Laboratory, Cold Spring Harbor, NY, 1972.

[22] G. Johnen, D. Kowlessur, B.A. Citron, S. Kaufman, Characterization of the wild-type form of $4 \alpha$-carbinolamine dehydratase and two naturally occurring mutants associated with hyperphenylalaninemia, Proc. Natl. Acad. Sci. USA 92 (1995) 12384-12388.

[23] R.G.H. Cotton, A pteridine adsorbant for affinity chromatography, FEBS Lett. 44 (1974) 290-292.

[24] H. Fujisawa, H. Nakata, Tryptophan 5-monooxygenase from rat brain stem, Methods Enzymol. 142 (1987) 83-87.

[25] P.A. Friedman, A.H. Kappelman, S. Kaufman, Partial pu- rification and characterization of tryptophan hydroxylase from rabbit hindbrain, J. Biol. Chem. 247 (1972) 4165-4173.

[26] O.H. Lowry, N.J. Rosebrough, A.L. Farr, R.J. Randall, Protein measurement with the folin phenol reagent, J. Biol. Chem. 193 (1951) 265-275.

[27] U.K. Laemmli, Cleavage of structural proteins during the assembly of the head of bacteriophage T4, Nature 227 (1970) 680-685.

[28] Y. Furukawa, N. Ikuta, S. Omata, T. Yamauchi, T. Isobe, T. Ichimura, Demonstration of the phosphorylation-dependent interaction of tryptophan hydroxylase with the 14-3-3 protein, Biochem. Biophys. Res. Commun. 194 (1993) 144 149.

[29] D. Kowlessur, B.A. Citron, S. Kaufman, Recombinant human phenylalanine hydroxylase: novel regulatory and structural properties, Arch. Biochem. Biophys. 333 (1996) 85-95.

[30] S. Kaufman, Studies on the mechanism of phenylalanine hydroxylase: detection of an intermediate, in: W.P. Pfleiderer (Ed.), Chemistry and Biology of Pteridines, Walter de Gruyter, Berlin, 1975, pp. 291-301.

[31] S. Kaufman, On the nature of an intermediate that is formed during the enzymatic conversion of phenylalanine to tyrosine, Adv. Exp. Med. Biol. 74 (1976) 91-102.

[32] M.D. Davis, S. Kaufman, Evidence for the formation of the $4 \alpha$-carbinolamine during the tyrosine-dependent oxidation of tetrahydrobiopterin by rat liver phenylalanine hydroxylase, J. Biol. Chem. 264 (1989) 8585-8596.

[33] C.Y. Huang, E.E. Max, S. Kaufman, Purification and characterization of phenylalanine hydroxylase-stimulating protein from rat liver, J. Biol. Chem. 248 (1973) 4235-4241.

[34] M.D. Davis, S. Kaufman, S. Milstein, A modified ferrozine method for the measurement of enzyme-bound iron, J. Biochem. Biophys. Methods 13 (1986) 39-45.

[35] J.H. Tong, S. Kaufman, Tryptophan hydroxylase. Purification and some properties of the enzyme from rabbit hindbrain, J. Biol. Chem. 250 (1975) 4152-4158.

[36] E. Jequier, D.S. Robinson, W. Lovenberg, A. Sjoerdsma, Further studies on tryptophan hydroxylase in rat brainstem and beef pineal, Biochem. Pharmacol. 18 (1969) 1071-1081.

[37] M.D. Davis, P. Ribeiro, J. Tipper, S. Kaufman, '7-Tetrahydrobiopterin,' a naturally occurring analogue of tetrahydrobiopterin, is a cofactor for and a potential inhibitor of the aromatic amino acid hydroxylases, Proc. Natl. Acad. Sci. USA 89 (1992) 10109-101113.

[38] M.D. Davis, S. Kaufman, 7-Tetrahydrobiopterin is an uncoupled cofactor for rat hepatic phenylalanine hydroxylase, FEBS Lett. 285 (1991) 17-20.

[39] T. Kato, T. Yamaguchi, T. Nagatsu, T. Sugimoto, S. Matsuura, Effects of structures of tetrahydropterin cofactors on rat brain tryptophan hydroxylase, Biochim. Biophys. Acta 611 (1980) 241-250.

[40] T.A. Dix, G.E. Bollag, P.L. Domanico, S.J. Benkovic, Phenylalanine hydroxylase: absolute configuration and source of oxygen of the $4 \alpha$-hydroxytetrahydropterin species, Biochemistry 24 (1985) 2955-2958.

[41] J. Haavik, T. Flatmark, Isolation and characterization of 
tetrahydrobiopterin oxidation products generated in the tyrosine monooxygenase reaction, Eur. J. Biochem. 168 (1987) 21-26.

[42] H. Nakata, H. Fujisawa, Purification and properties of tryptophan 5-monooxygenase from rat brain stem, Eur. J. Biochem. 122 (1982) 41-47.

[43] T.L. Perry, S. Hassen, B. Tischler, R. Bunting, S. Diamond, Glutamine depletion in phenylketonuria, New Engl. J. Med. 282 (1970) 761-766.

[44] T. Yamaguchi, M. Sawada, T. Kato, T. Nagatsu, Demonstration of tryptophan 5-monooxygenase activity in human brain by highly sensitive HPLC with fluorometric detection, Biochem. Int. 2 (1981) 295-303.

[45] S. Hosoda, W. Nakamura, K. Takatsuki, Properties of tryptophan hydroxylase from human carcinoid tumor, Biochim. Biophys. Acta 482 (1977) 27-34.

[46] C. McKean, The effects of high phenylalanine concentration on serotonin and catecholamine metabolism in the human brain, Brain Res. 47 (1972) 469-476.

[47] D. Dawson, C.J. van den Heuvel, Integrating the action of melatonin on human physiology, Ann. Med. 30 (1998) 95102.

[48] M. Ehret, C.D. Cash, M. Hamon, M. Maitre, Formal demonstration of the phosphorylation of rat brain tryptophan hydroxylase by $\mathrm{Ca}^{2+}$ /calmodulin-dependent protein kinase, J. Neurochem. 52 (1989) 1886-1891.

[49] U. Banik, G.A. Wang, P.D. Wagner, S. Kaufman, Interaction of phosphorylated tryptophan hydroxylase with 14-3-3, J. Biol. Chem. 272 (1997) 26219-26225.
[50] M.D. Kuhn, R.J. Arthur, C. States, Phosphorylation and activation of brain tryptophan hydroxylase: identification of serine-58 as a substrate site for protein kinase A, J. Neurochem. 68 (1997) 2220-2223.

[51] M.C. Darmon, B. Guibert, V. Leviel, M. Ehret, M. Maitre, J. Mallet, Sequence of two mRNAs encoding active rat tryptophan hydroxylase, J. Neurochem. 51 (1988) 312-316.

[52] S. Kaufman, D.B. Fisher, Pterin-requiring aromatic amino acid hydroxylases, in: O. Hayaishi (Ed.), Molecular Mechanisms of Oxygen Activation, Academic Press, New York, 1974, pp. 285-369.

[53] S. Kaufman, Tetrahydrobiopterin, Johns Hopkins University Press, Baltimore, MD, 1997.

[54] S. Kaufman, A protein that stimulates rat liver phenylalanine hydroxylase, J. Biol. Chem. 245 (1970) 4751-4759.

[55] M.D. Davis, S. Kaufman, S. Milstien, Distribution of $4 \alpha-$ hydroxytetrahydropterin dehydratase in rat tissues: comparison with the aromatic amino acid hydroxylases, FEBS Lett. 302 (1992) 73-76.

[56] B.A. Citron, S. Kaufman, S. Milstein, E.W. Naylor, C.L. Greene, M.D. Davis, Mutation in the $4 \alpha$-carbinolamine dehydratase gene leads to mild hyperphenylalaninemia with defective cofactor metabolism, Am. J. Hum. Genet. 53 (1993) 768-774.

[57] S. Kaufman, Studies on the mechanism of the enzymatic conversion of phenylalanine to tyrosine, J. Biol. Chem. 234 (1959) 2677-2682. 